\title{
Frequencies of lipopolysaccharide core types in Escherichia coli strains from bacteraemic patients
}

\author{
Ben J. Appelmelk, ${ }^{1}$ Yun-Qing An, ${ }^{1}$ Thecla A. M. Hekker, ${ }^{1}$ \\ Lambertus G. Thijs, ${ }^{2}$ David M. MacLaren ${ }^{1}$ and Johannes de Graaf ${ }^{1}$
}

Author for correspondence: Ben J. Appelmelk. Tel. +3120 5483952. Fax: +31206447151.

\footnotetext{
1 Department of Medical Microbiology and

2 Medical Intensive Care

Unit, Vrije Universiteit, van der Boechorststraat 7, 1081 BT Amsterdam, The Netherlands
}

\begin{abstract}
We have investigated the distribution of the various core types (R1, R2, R3, R4 and K-12) in 138 Escherichia coli isolates obtained from positive blood cultures. Rabbit antisera, raised against five rough strains expressing the respective core types, were made monospecific by extensive absorption. The reactivity of the antisera was tested in ELISA with bacterial cells that had been autoclaved for full exposure of core epitopes. One hundred and thirty strains could be typed directly, while eight strains required prior digestion with proteinase $K$ for removal of cross-reactions. Ninety-four of the strains (68\%) expressed the R1 type, and $9(6.5 \%), 12(8.7 \%), 7(5.1 \%)$ and $3(2.2 \%)$ strains expressed the R2, R3, R4 and K-12 core types, respectively. An R1R4 mixed core type, hitherto not yet described, was found in $13(9.4 \%)$ strains. Results obtained with polyclonal antisera were in agreement with those obtained with monoclonal antibodies to the R1, R2 and R3 core types. Core typing may serve as an additional serological marker next to conventional typing of $\mathrm{O}-, \mathrm{H}$ - and $\mathrm{K}$-antigens.
\end{abstract}

Keywords: Escherichia coli, lipopolysaccharide, core serotypes, bacteraemia

\section{INTRODUCTION}

Lipopolysaccharide (LPS, endotoxin), a major bacterial cell surface component, is known to play a crucial role in the pathogenesis of bacteraemia, sepsis and shock caused by Gram-negative bacteria. LPS comprises three regions: (a) the $\mathrm{O}$-antigen, a polysaccharide consisting of covalently linked repetitive oligosaccharide building blocks; (b) the core, a non-repetitive oligosaccharide of about nine sugar residues; and (c) lipid A, an acylated disaccharide responsible for LPS toxicity.

Anti-O antibodies to LPS are highly protective (Kirkland \& Ziegler, 1984). Most of the O-antigens known differ from each other in chemical composition and structure. In contrast, only five core types are known in Escherichia coli (Holst \& Brade, 1992), designated R1, R2, R3, R4 and K12. Immunotherapy of experimental Gram-negative bacterial sepsis with antisera to purified R1 and R4 LPS has been described (Lugowski et al., 1992) and similar treatment of patients is conceivable. Knowledge of the distribution of core types in strains of E. coli isolated from bacteraemic patients would be of great value to aid such

Abbreviations: mAbs, monoclonal antibodies; pAbs, polyclonal antisera. therapy, in the same way as O-serotyping (Cryz et al., 1991). Also, determination of core serotypes can be used for characterization of bacteria as an addition to conventional serotyping schemes based on $\mathrm{O}-, \mathrm{K}$ - and $\mathrm{H}$ antigens. We now report the distribution of core serotypes of $138 \mathrm{E}$. coli strains isolated from bacteraemic patients.

\section{METHODS}

Rabbit antisera. Rabbit polyclonal antisera (pAbs) were prepared by $\mathrm{H}$. Brade (Forschungsinstitut Borstel, Borstel, Germany). Rabbits were vaccinated by intravenous inoculation with $50,100,100$ and $200 \mu \mathrm{g}$ heat-killed, lyophilized bacteria on days $0,4,7$ and 11 , respectively; rabbits were bled at day 16 . Serum was stored frozen in $100 \mu$ l aliquots. E. coli strains F470, F576, F653, F2513 and W3100 expressing the R1, R2, R3, R4 and $\mathrm{K}-12$ core type, respectively, were from the culture collection of G. Schmidt (Borstel) and these strains were used for preparing pAbs. pAbs were made monospecific for a given E. coli LPS core type by absorption. The procedure as applied to anti-R1 antiserum is given as an example: $100 \mu \mathrm{l}$ of anti-R1 antiserum was incubated under rotation with autoclaved $\left(20 \mathrm{~min}, 121^{\circ} \mathrm{C}\right.$ ) R2, R3 and R4 bacteria (each $5 \times 10^{8}$ c.f.u. in $100 \mu \mathrm{l}$ ) for $1 \mathrm{~h}$ at $37^{\circ} \mathrm{C}$. The mixture was centrifuged for $10 \mathrm{~min}$ at $14000 \mathrm{~g}$ and the absorption procedure was repeated three times. pAbs to R1-4 were not absorbed with $\mathrm{K}-12$ cells. The anti-K-12 antiserum, obtained in the final stage of this study, was absorbed with R1, R2, R3 and R4 bacteria. 
Monoclonal antibodies. Monoclonal antibodies (mAbs) to core types R1 ( $\alpha$-R1, code VN2 423-1), R2 ( $\alpha-\mathrm{R} 2$, V1 39-1) and R3 $(\alpha-\mathrm{R} 3$, V4 178-13) were provided in purified form $\left(1 \mathrm{mg} \mathrm{ml}^{-1}\right.$ ) by Dr F. di Padova (Sandoz Pharma, Basel, Switzerland) and stored at $4{ }^{\circ} \mathrm{C}$ with $0.01 \%$ merthiolate as a preserving agent. The preparation of these $m A b s$ will be described elsewhere. mAbs specific for the R4 or K-12 core types were not available to us.

Clinical isolates. E. coli strains $(n=138)$ were isolated from positive blood cultures using the BACTEC system (BectonDickinson) and were identified by conventional biochemical testing; strains were obtained during a time period of two years.

Serotyping of $\mathbf{O}$ - and K-antigen. A subset of 30 strains was serotyped for $\mathrm{O}$ - and $\mathrm{K}$-antigen at the Rijksinstituut voor Volksgezondheid and Mileuhygiene (Bilthoven, The Netherlands).

Bacterial antigens. Purified R1-R4 and K-12 LPS, isolated by the phenol/chloroform/petroleum ether method, were a generous gift of Dr H. Brade. LPS $\left(1 \mathrm{mg} \mathrm{ml}^{-1}\right.$ in water with $01 \%$ triethylamine) were stored at $4{ }^{\circ} \mathrm{C}$. Crude bacterial antigens were prepared by growing bacteria, previously subcultured at least twice, overnight in brain heart infusion broth after which they were washed in phosphate-buffered saline (PBS), $\mathrm{pH} 7 \cdot 2$, brought to $\mathrm{OD}_{650}=0.3$ (corresponding to about $5 \times 10^{8}$ c.f.u. $\mathrm{ml}^{-1}$ ) and autoclaved. In some initial experiments bacteria were boiled $\left(20 \mathrm{~min}, 100^{\circ} \mathrm{C}\right)$ instead of autoclaved; for some experiments (see Results) boiled or autoclaved bacteria were centrifuged ( $30 \mathrm{~min}, 3000 \mathrm{~g}$ ) which resulted in a pellet and a supernatant. For testing in ELISA, pellet and supernatant were separately diluted $1: 1000$ in PBS and coated; in addition, part of the heated/autoclaved bacteria were directly diluted 1:1000 and coated. For determination of core type in some strains it proved essential (see Results) to destruct noncarbohydrate antigens: autoclaved cells in PBS $(0.5 \mathrm{ml}$, $2.5 \times 10^{8}$ c.f.u. $)$ were first incubated $\left(0.5 \mathrm{~h}, 37^{\circ} \mathrm{C}\right)$ with $10 \mu \mathrm{g}$ DNase (DNase I from bovine pancreas, grade II, Boehringer Mannheim) and $5 \mu \mathrm{g}$ RNase (RNase I, from bovine pancreas, $\mathrm{BDH}$ ), followed by incubation with $250 \mu \mathrm{g}$ proteinase $\mathrm{K}$ (Merck) for $90 \mathrm{~min}$ at $37^{\circ} \mathrm{C}$. Finally, for destruction of enzymes, treated cells were heated for $30 \mathrm{~min}$, at $100^{\circ} \mathrm{C}$. For destruction of carbohydrate antigens, autoclaved cells were incubated with $2.5 \mathrm{mM}$ periodate for $2 \mathrm{~h}$ at room temperature, followed by neutralization with 4 drops of glycerol ( $30 \mathrm{~min}$, room temperature). The various crude bacterial antigen preparations were stored frozen, at $4{ }^{\circ} \mathrm{C}$.

ELISA. Determination of reactivity of $\mathrm{mAbs}$ and $\mathrm{pAbs}$ was performed by ELISA. Polystyrene plates were used for coating; LPS ( $1 \mu \mathrm{g} \mathrm{mi}^{-1}$ in PBS) was coated overnight at room temperature. Unless indicated otherwise, crude bacterial antigens were coated at $5 \times 10^{5}$ c.f.u. $\mathrm{ml}^{-1}$. Plates were washed thrice in PBS containing $0.05 \%$ Tween 80 (PBST) and antibodies diluted in PBST were added. $\mathrm{mAbs}$ were tested at $1 \mu \mathrm{g} \mathrm{m} \mathrm{m}^{-1}$. Dilutions of $\mathrm{pAbs}$ used are stated in the individual experiments. Antibodies were incubated overnight at room temperature, plates were washed thrice in PBST, and conjugates diluted $1: 1000$ in PBST containing $0.5 \%$ goat serum were added. For $\mathrm{mAbs}$, goat anti-mouse $\operatorname{IgG}(\mathrm{H}+\mathrm{L})$, linked to horseradish peroxidase (HRP) was used (American Qualex); for rabbit antisera, HRP-linked goat anti-rabbit $\operatorname{IgG}(\mathrm{H}+\mathrm{L}$ ) (Nordic) was used. After $2 \mathrm{~h}$ at $37^{\circ} \mathrm{C}$, plates were washed and colour was developed for $30 \mathrm{~min}$ at room temperature in $0.1 \mathrm{M}$ sodium phosphate-citrate buffer, $\mathrm{pH} 5.5$ containing orthophenylene diamine $\left(1 \mathrm{mg} \mathrm{ml}^{-1}\right)$ and hydrogen peroxide $(0.015 \%)$; plates were stopped with $(1.5 \mathrm{M}$ $\mathrm{H}_{2} \mathrm{SO}_{4}$ and $\mathrm{OD}$ was read at $492 \mathrm{~nm}$. Controls included wells coated with LPS or bacteria where PBST was substituted for anti-core antibody, and 'PBS-coated' wells that were otherwise treated as normal. All determinations were done on at least two independent occasions with similar results; the data shown are representative.

\section{RESULTS}

\section{Selection of bacterial antigens for coating of ELISA plates}

Firstly, we investigated how to expose optimally core epitopes for binding with antibodies. The strain tested (90/894) was of the O18:K1 serotype. mAbs $\alpha$-R1, $\alpha$-R2 and $\alpha-\mathrm{R} 3$ were then tested for reactivity for the various bacterial antigen preparations (see Methods). Autoclaved material, not separated into pellet and supernatant, consistently yielded the highest $\mathrm{OD}_{492}$ value, and hence this material was used for further tests.

\section{Characterization of mAbs and pAbs}

The binding of the three core-specific $\mathrm{mAbs}$ to purified LPS of R1 to R4, as well as to autoclaved rough strain bacteria, and four clinical isolates was measured. The results are shown in Table 1 . The mAbs reacted very specifically with purified rough strain LPS or autoclaved bacteria of only one chemotype. Clearly, strains $89 / 106$, $90 / 606$ and $90 / 922$ expressed the R1, R2 and R3 chemotype, respectively. Strain 89/500 expressed R4 (see below). We then tested the non-absorbed pAbs with the rough strains for their reactivity. pAbs were tested in serial two- or threefold dilutions, starting at 1:1000 or $1: 1500$. At high dilutions (about $1: 20000$ ), non-absorbed pAbs were sufficiently monospecific to discriminate core types R1, R2 and R4 when purified LPS of the E. coli rough strains was used as coating material (data not shown). In contrast, purified R3 LPS reacted almost equally strongly with anti-R 3 and anti-R 4 antiserum over the entire titration curves (data not shown). When autoclaved $E$. coli R1 to R4 cells, or clinical isolates $89 / 106,90 / 606,90 / 922$ and $89 / 500$ were coated at $5 \times 10^{5}$ c.f.u. $\mathrm{ml}^{-1}$, in all cases the non-absorbed pAbs displayed such strong cross-reactivities as to be of no value for serotyping. An example (strain 89/106) is given in Fig. 1. Therefore, to make the antisera suitable for serotyping they were absorbed as described in Methods. Various coating concentrations of autoclaved bacteria were tested and $5 \times 10^{5}$ c.f.u. $\mathrm{ml}^{-1}$ was found to be optimal, i.e. at higher concentrations even the absorbed antisera started to display cross-reactions, while at lower concentrations signals dropped strongly. Hence, unless indicated otherwise, $5 \times 10^{5}$ c.f.u. $\mathrm{ml}^{-1}$ were used for coating. Results thus obtained with absorbed antisera are shown in Table 1. Based on the data of Table 1 a tentative core chemotype was assigned to a bacterial strain if the $\mathrm{OD}_{492}$ value obtained with one of the four absorbed $\mathrm{pAbs}$ $(\alpha-\mathrm{R} 1,-\mathrm{R} 2,-\mathrm{R} 3$ and $-\mathrm{R} 4$, tested in twofold dilutions ranging from $1: 1000$ to $1: 16000$ ) was at least twice that obtained with all three others. Antiserum to K-12 was not used except for some experiments (see below). In parallel, the reactivity of the three $\mathrm{mAbs}$ (tested at $1 \mu \mathrm{g} \mathrm{ml}^{-1}$ ) with that strain was determined. 
Table 1. Binding of mAbs and absorbed monospecific antisera to R-core chemotypes of E. coli with purified LPS and autoclaved bacterial cells

Binding was measured in ELISA at a mAb concentration of $1 \mu \mathrm{g} \mathrm{ml}^{-1}$; antisera were tested at a $1: 1500$ dilution.

\begin{tabular}{|c|c|c|c|c|c|c|c|c|}
\hline \multirow[t]{2}{*}{ Antigen } & \multicolumn{4}{|c|}{$\mathbf{m A b}$} & \multicolumn{4}{|c|}{$\mathbf{p} \mathbf{A b}$} \\
\hline & $\alpha-\mathbf{R} 1$ & $\alpha-\mathbf{R 2}$ & $\alpha-\mathbf{R} 3$ & Control* & $\alpha-\mathbf{R} 1$ & $\alpha-\mathrm{R} 2$ & $\alpha-\mathbf{R} 3$ & $\alpha-\mathrm{R} 4$ \\
\hline LPS R1† & $>\ddagger$ & $0 \cdot 2$ & $0 \cdot 2$ & $0 \cdot 1$ & $>$ & $0 \cdot 3$ & $0 \cdot 2$ & $0 \cdot 3$ \\
\hline LPS R2† & $0 \cdot 2$ & $>$ & $0 \cdot 1$ & $0 \cdot 2$ & $0 \cdot 6$ & $2 \cdot 3$ & $0 \cdot 5$ & $0 \cdot 5$ \\
\hline LPS R3† & $0 \cdot 2$ & $0 \cdot 2$ & $>$ & $0 \cdot 1$ & $0 \cdot 3$ & $0 \cdot 4$ & $>$ & $0 \cdot 3$ \\
\hline LPS R4t & $0 \cdot 2$ & $0 \cdot 2$ & $0 \cdot 2$ & $0 \cdot 1$ & 0.5 & $0 \cdot 4$ & 0.6 & $>$ \\
\hline Bacteria R1S & $>$ & $0 \cdot 2$ & $0 \cdot 1$ & $0 \cdot 2$ & $>$ & 0.5 & 0.5 & $0 \cdot 5$ \\
\hline Bacteria R2 $\int$ & $0 \cdot 3$ & $>$ & $0 \cdot 2$ & $0 \cdot 2$ & $0 \cdot 4$ & $1 \cdot 8$ & $0 \cdot 6$ & $0 \cdot 3$ \\
\hline Bacteria R3 & $0 \cdot 3$ & $0 \cdot 2$ & $>$ & $0 \cdot 2$ & 0.5 & $0 \cdot 7$ & $>$ & $0 \cdot 3$ \\
\hline Bacteria R4§ & $0 \cdot 3$ & $0 \cdot 2$ & $0 \cdot 1$ & $0 \cdot 2$ & $0 \cdot 3$ & $0 \cdot 3$ & 0.5 & $>$ \\
\hline Strain $89 / 106 \|$ & $>$ & $0 \cdot 2$ & $0 \cdot 2$ & $0 \cdot 2$ & $>$ & 0.5 & 0.7 & 0.5 \\
\hline Strain $90 / 606 \|$ & $0 \cdot 3$ & $>$ & $0 \cdot 2$ & $0 \cdot 2$ & 0.4 & $1 \cdot 5$ & 0.6 & $0 \cdot 3$ \\
\hline Strain $90 / 922 \|$ & $0 \cdot 2$ & $0 \cdot 2$ & $>$ & $0 \cdot 1$ & 0.4 & $0 \cdot 5$ & $>$ & $0 \cdot 4$ \\
\hline Strain $89 / 500 \|$ & 0.3 & $0 \cdot 2$ & $0 \cdot 2$ & $0 \cdot 2$ & 0.5 & $0 \cdot 3$ & $0 \cdot 2$ & $1 \cdot 6$ \\
\hline
\end{tabular}

* PBST used instead of $\mathrm{mAb}$.

†LPS from R1 to R4 E. coli rough strains were coated.

$\ddagger>$, OD value greater than $2 \cdot 5$.

$\$$ Autoclaved bacterial cells of $E$. coli rough strains were coated.

\| Strains 106, 606, 922 and 500 are clinical blood culture isolates of E. coli.

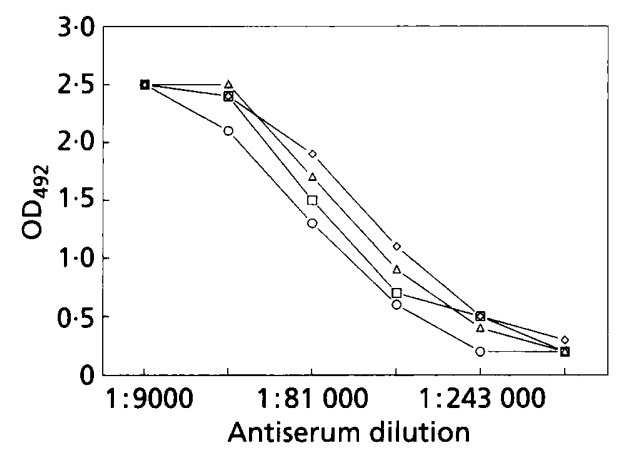

Fig. 1. Reactivity of non-absorbed rabbit anti-core antisera with an $E$. coli strain expressing the R1 core type. $\square$, Anti-R1; $\triangle$, anti-R2; $\diamond$, anti-R3; $O$, anti-R4.

\section{Determination of core chemotype in 138 clinical isolates obtained from bacteraemic patients}

Clinical isolates (138) obtained from positive blood cultures of bacteraemic patients were tested. For 108 strains, a definitive core type was directly assigned because the following three conditions were met. Firstly, the pAbs behaved according to the criteria defined above. Secondly, results with $\mathrm{mAbs}$ were clear-cut: $\mathrm{OD}_{492}$ values of the homologous reactions were always at least twice, and often 10-20 times, that of the heterologous reactions. In general, homologous $\mathrm{OD}_{492}$ values were in the range of
$1->2 \cdot 5$, whereas heterologous reactions were $<0.4$. Thirdly, mAbs and pAbs yielded identical results concerning the core type assigned. Of these 108 strains, 87 were of the R1 type, and 9 and 12 were of R2 and R3 chemotype, respectively.

For the remainder of the strains $(n=30)$ the three abovementioned conditions were not met and included the following.

1. Strains $(n=3)$ that reacted equally well with polyclonal $\alpha-\mathrm{R} 1$ and with $\alpha-\mathrm{R} 3$ antiserum and much less with $\alpha-\mathrm{R} 2$ and $\alpha-R 4$ antisera. These three strains reacted with the $\alpha$ $\mathrm{R} 1 \mathrm{mAb}\left(\mathrm{OD}_{492}\right.$ between 0.6 and 2.5$)$ and not with $\alpha-\mathrm{R} 2$ or $-\mathrm{R} 3 \mathrm{mAbs}\left(\mathrm{OD}_{492}<0 \cdot 2\right)$. An example of this putative R1R3 type is given in Fig. 2(a). We hypothesized that the R3 reaction observed might be due to cross-reactivities with non-LPS antigens; hence, autoclaved cells were treated with DNase, RNase and proteinase $\mathrm{K}$ and tested for binding. Much of the reactivity of the anti-R3 antiserum disappeared but the $\mathrm{OD}_{492}$ reached with the anti-R1 antiserum was not twice that reached with the other antisera (not shown). We then tested both nondigested and digested bacteria at a much higher coating concentration, i.e. $2.5 \times 10^{7}$ c.f.u. $\mathrm{ml}^{-1}$ (Fig. $2 \mathrm{~b}$, c). Fig. 2(b) shows the R1R3 pattern obtained at this higher coating concentration. Fig. 2(c) shows that after enzyme digestion the $\mathrm{R} 3$, but not the $\mathrm{R} 1$, reactivity had disappeared. In parallel, cells were treated with $2.5 \mathrm{mM}$ periodate to further identify the epitopes giving rise to the reactivity patterns observed. The results (Fig. $2 \mathrm{~d}$ ) demon- 

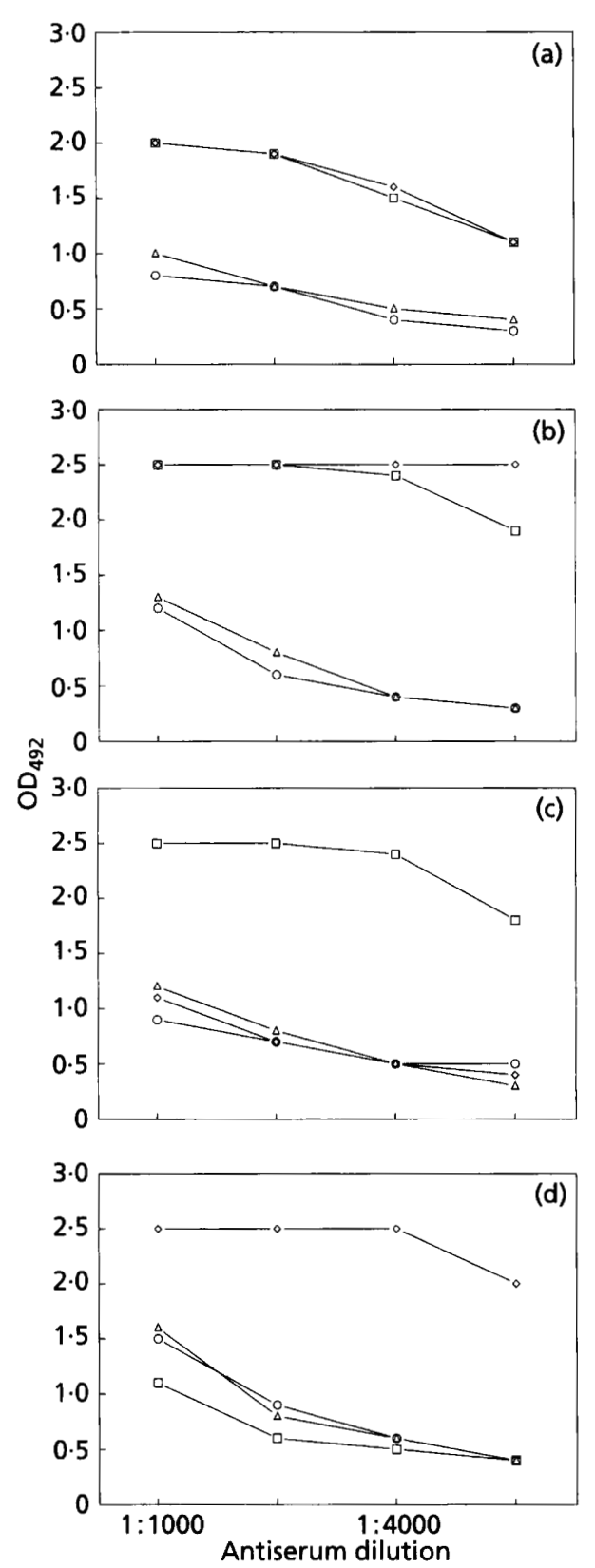

Fig. 2. Reactivity of anti-core antisera with an $E$. coli strain apparently expressing both R1 and R3 core types. For symbols, see legend to Fig. 1. (a) Binding to non-digested bacteria coated at $5 \times 10^{5}$ c.f.u. $\mathrm{ml}^{-1}$; (b) binding to non-digested bacteria coated at $2.5 \times 10^{7}$ c.f.u. $\mathrm{ml}^{-1}$; (c) binding to enzymetreated bacteria coated at $2.5 \times 10^{7}$ c.f.u. $\mathrm{ml}^{-1}$; (d) binding to periodate-treated bacteria coated at $2.5 \times 10^{7}$ c.f.u. $\mathrm{ml}^{-1}$.

strate that the $\mathrm{R} 1$ reactivity, but not the $\mathrm{R} 3$ one, was sensitive to periodation. The reactivity of the $\alpha-\mathrm{R} 1 \mathrm{mAb}$ was resistant to enzyme digestion and sensitive to periodation (not shown). These observations indicate that the $\mathrm{R} 3$ reactivity is not due to a carbohydrate antigen (i.e. LPS). The other two strains of this group behaved similarly. Hence the three strains of this group were assigned the R1 chemotype. For further validation, the procedures of enzymic digestion and periodation were imposed upon the four $E$. coli rough strains and their purified LPS. Periodate treatment destroyed reactivity of absorbed $\mathrm{pAbs}$ and $\mathrm{mAbs}$ with LPS and bacteria, while proteolytic treatment was without effect (data not shown).

2. Strains $(n=7)$ that are $\mathrm{R} 4$ as determined with pAbs. $\mathrm{OD}_{492}$ values with $\alpha-\mathrm{R} 2$ and $\alpha-\mathrm{R} 3 \mathrm{mAbs}$ were $<0.2$; with the $\alpha-\mathrm{R} 1 \mathrm{mAb}$ they ranged from $0 \cdot 2$ to $0 \cdot 4$. As no $\alpha-\mathrm{R} 4$ $\mathrm{mAb}$ was available for comparison, we sought evidence that the epitopes recognized by the anti-R4 antiserum are located on the LPS molecules of the strain tested; thus, autoclaved cells were subjected to enzymic treatment and periodation. Bacteria were coated both at $5 \times 10^{5}$ and $2.5 \times 10^{7}$ c.f.u. $\mathrm{ml}^{-1}$, and tested for reactivity. The epitopes recognized were resistant to enzyme digestion and sensitive to periodation; this was observed for all seven strains in this group. We therefore assigned the R4 chemotype to these strains.

3. Strains $(n=12)$ that reacted equally well with $\alpha-\mathrm{R} 1$ and $\alpha-\mathrm{R} 4 \mathrm{pAbs}$, and not, or significantly less so, with $\alpha$-R2 and $\alpha-\mathrm{R} 3 \mathrm{pAbs}$. With $\mathrm{mAbs}$ the following results were obtained: $\alpha-\mathrm{R} 2$ and $\alpha-\mathrm{R} 3$ yielded $\mathrm{OD}_{492}<0 \cdot 2$; for the $\alpha$ $\mathrm{R} 1 \mathrm{mAb}, \mathrm{OD}_{492}$ values ranged between $0 \cdot 8$ and $2 \cdot 3$. An example is given in Fig. 3(a). Bacteria were subjected to enzymic digestion and periodation (Fig. 3b, c). R1 and R4 reactivities behaved identically, i.e. they were resistant to proteolytic digestion, and sensitive to periodate. Proteinase $\mathrm{K}$ resistance and periodate sensitivity of the R1R4 reactivity was seen for all 12 strains comprising this group. We therefore assigned the R1R4 mixed core type to these strains.

4. For a group of four strains, the pAbs reacted well but none of the antisera yielded an $\mathrm{OD}_{492}$ value twice that of the other antisera; strains did not react with $\alpha$-R2 and $\alpha$ $\mathrm{R} 3 \mathrm{mAbs}\left(\mathrm{OD}_{492}<0 \cdot 2\right)$; with the $\alpha$-R1 mAbs, $\mathrm{OD}_{492}$ values between 0.5 and 1.4 were reached. After enzymic digestion, bacteria were tested at $2.5 \times 10^{7}$ c.f.u. $\mathrm{ml}^{-1}$ : cross-reactivities had now disappeared and anti-R1 antiserum reacted with $\mathrm{OD}_{492}$ values at least twice that of other antisera. Thus, we assigned the $\mathrm{R} 1$ core type to these strains.

5. Finally, four strains were encountered that reacted only weakly with the pAbs $\left(\mathrm{OD}_{492}<1.0\right.$ even at $\left.1: 1000\right)$; none of the $\mathrm{pAbs}$ reacted with $\mathrm{OD}_{492}$ values twice that of the others. With the $\mathrm{mAbs} \mathrm{OD}_{492}$ values $<0.4$ were obtained. After digestion, bacteria were tested at $2.5 \times 10^{7}$ c.f.u. $\mathrm{ml}^{-1}$. For one strain, $\alpha-\mathrm{R} 1$ and $\alpha-\mathrm{R} 4 \mathrm{pAbs}$ and $\alpha-\mathrm{R} 1 \mathrm{mAb}$ yielded $\mathrm{OD}_{492}$ values of $2,2.5$ and 1 , respectively. Only a low binding was seen with the other pAbs and mAbs. Periodation destroyed this R1R4 reactivity (data not shown). Thus, this strain expressed the mixed R1R4 core type described above.

After digestion and testing at $2.5 \times 10^{7}$ c.f.u. $\mathrm{ml}^{-1}$, the three remaining strains still did not react with either $\mathrm{pAbs}$ and $\mathrm{mAbs}$ and we investigated if they might express the $\mathrm{K}-12$ core type. First, the anti-K-12 antiserum that in the course of our studies became available to us, was absorbed (see Methods). Indeed, the $\mathrm{OD}_{492}$ values obtained with the absorbed $\mathrm{K}-12$ antisera were more than twice the 

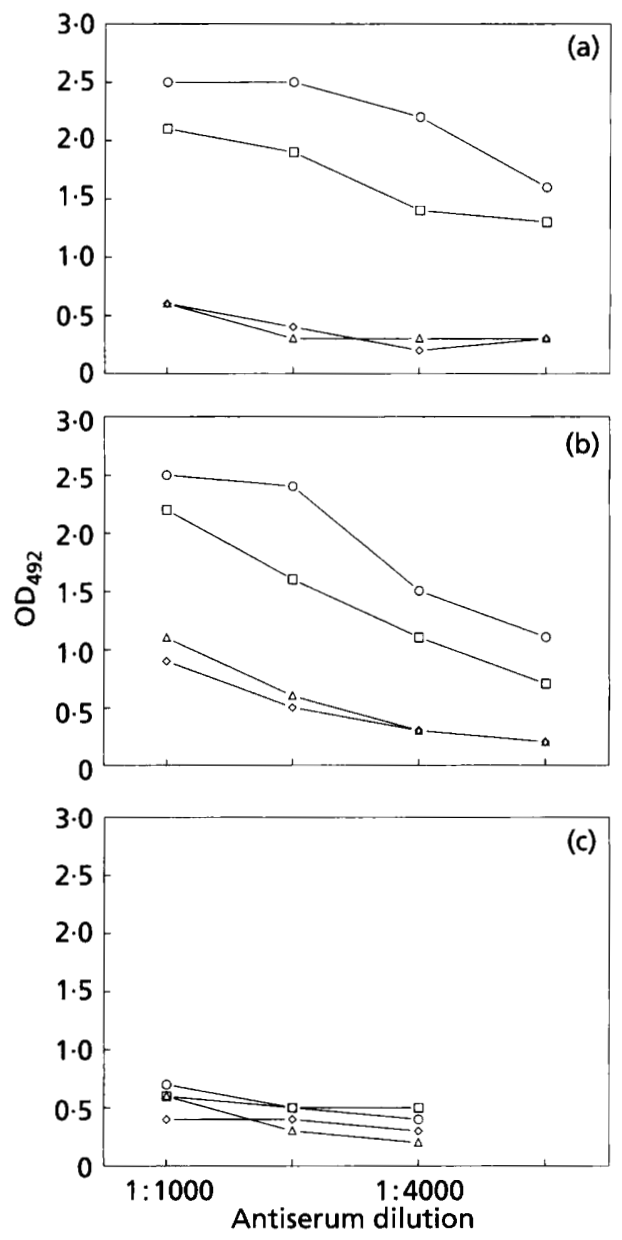

Fig. 3. Reactivity of anti-core antisera with an $E$. coli strain expressing the mixed R1R4 core type. For symbols, see legend to Fig. 1. (a) Binding to non-digested bacteria; (b) binding to enzyme-digested cells; (c) binding to periodate-treated cells. Bacteria were coated at $5 \times 10^{5}$ c.f.u. $\mathrm{ml}^{-1}$.

$\mathrm{OD}_{492}$ obtained with the other absorbed anti- $\mathrm{R}$ antisera. This occurred both when untreated bacteria at $5 \times 10^{5}$ c.f.u. $\mathrm{ml}^{-1}$ were used for coating, as well as after enzyme digestion at $2.5 \times 10^{7}$ c.f.u. $\mathrm{ml}^{-1}$; periodation destroyed this reaction (data not shown). For further validation, we tested the reactivity of the absorbed anti$\mathrm{K}-12$ antiserum with the panel of rough strain bacteria and purified LPS. Again, sensitivity to periodate and insensitivity to proteinase $\mathrm{K}$ was observed. Therefore, these three strains were assigned the $\mathrm{K}-12$ chemotype.

In short, for all of the 138 strains tested a core type could be assigned: 94 of the strains were R1 $(68 \%), 9$ were R2 $(6.5 \%), 12$ were R3 $(8.7 \%), 7$ were R4 (5.1\%), 3 were $\mathrm{K}-12(2 \cdot 2 \%)$ and 13 expressed the mixed R1R4 core type $(9 \cdot 4 \%)$. Twenty-three of the 31 strains tested could be O-serotyped and 15 of those were serotypes O1, O2, O4, O6, O8, O18 and O75. These 15 strains all expressed the $\mathrm{R} 1$ core type. The $\mathrm{R} 3$ core type occurred in two O77 strains; the R1R4 core was found in a O83 strain and in one 086 strain.

\section{DISCUSSION}

In this study we demonstrated that rabbit antisera, raised against E. coli strains expressing the five currently known core types, can be used for serotyping of clinical isolates. To do so, conventional procedures were followed, i.e. sera were absorbed to eliminate cross-reactivities (Fig. 1, Table 1) and secondly, bacteria were heated. Classically, heating has been used to remove capsular material to allow for serotyping of O-antigens (Orskov \& Orskov, 1984). More recently, it has been shown that heating improves exposure of otherwise hidden LPS core epitopes (Aydintug et al., 1989). In agreement with other investigators we found that autoclaving was superior to heating at $100{ }^{\circ} \mathrm{C}$ (Ørskov \& Ørskov, 1984).

We considered a strain as typeable with absorbed pAbs if the $\mathrm{OD}_{492}$ reached with one of the $\mathrm{pAbs}$ was at least twice that of the other antisera (Table 1). Only eight strains were not directly typeable by means of pAbs, i.e. groups 1 and 4, and the R1R 4 strain of group 5. We succeeded in eliminating cross-reactivities by incubation of the bacteria with proteinase $\mathrm{K}$ (Fig. 2). It is conceivable that these proteinase K-sensitive cross-reactivities, still present in absorbed antisera, are due to the fact that the rough E. coli strains used for preparing the pAbs are non-isogenic, i.e. the rough strains differ from each other in more than their LPS. Thus, rough strain F653 (R3 core) may express a protein not present in the other rough strains used. Hence, absorbed antisera to F653 may still contain antibodies to this protein. When a clinical isolate expressed the R1 LPS core and this protein, a R1R3 pattern was obtained of which the $\mathrm{R} 3$ reactivity was sensitive to proteinase K (group 1).

In one study (Gibb et al., 1992), published during the course of this investigation, the distribution of R1, R2 and $\mathrm{R} 3$ core types in a large collection of clinical isolates was determined. Gibb et al. (1992) used $\alpha-\mathrm{R} 1, \alpha-\mathrm{R} 2$ and $\alpha-\mathrm{R} 3$ $\mathrm{mAbs}$; the R1, R2 and R3 core types occurred in percentages of $68,7 \cdot 7$ and $9 \cdot 8$, respectively. These values are almost identical to the data presented in this paper. Viret $e$ t al. (1992) detected the R1 core type in 7 out of 10 purified E. coli LPS. Thus, in three studies, the R1 core type was the most commonly encountered one, being found in some $70 \%$ of the isolates. In one other study (Nnalue et al., 1992) the R2 core was found to occur in 11 out of $73(15 \%)$ E. coli strains; these authors did not attempt to detect the other core types. Like Gibb et al. (1992), we encountered many of the O-serotypes that are usually found in strains isolated from positive blood cultures.

Gibb et al. (1992) encountered 14\% core non-typeable strains. Given our results, it is possible that some of these strains may have expressed R4 or K-12. It is also possible that some of the R1 strains in fact expressed R1R4. The R1R4 mixed core type has not been described previously. As subculturing did not result in a separation of core types, we infer that this R1R4 core type is not an artefact. At least three situations are conceivable. Firstly, bacteria express both complete R1 and R4 LPS molecules. Secondly, bacteria express a single type of core molecule 
that contains both the R1 and the R4 immunodominarit epitopes. Thirdly, bacteria express one type of core molecule only that is chemically different from both $\mathrm{R} 1$ and $\mathrm{R} 4$ type but cross-reactive with both $\alpha-\mathrm{R} 1$ and $\alpha-\mathrm{R} 4$ LPS antisera. Evidently, structural and more detailed immunological studies are required to clarify the nature of the R1R4 LPS core.

\section{ACKNOWLEDGEMENTS}

We thank Dr H. Brade (Borstel, Germany) for preparing the antisera and for providing LPS and bacteria. J. J. Maaskant and T. Verboom (Amsterdam) were of great help in subculturing strains. Franco Di Padova generously provided us with monoclonal antibodies to R1, R2 and R3 LPS. We thank Dr A. J. van Winkelhoff (Amsterdam) for suggestions and carefully reading the manuscript.

\section{REFERENCES}

Aydintug, M., Inzana, T. J., Letonja, T., Davis, W. C. \& Corbeil, L. B. (1989). Cross-reactivity of monoclonal antibodies to Escherichia coli J5 with heterologous Gram-negative bacteria and extracted lipopolysaccharides. J Infect Dis 160, 846-857.

Cryz, S. J., Jr, Fürer, E., Sadoff, J. C., Fredeking, T., Que, J. U. \& Cross, A. (1991). Production and characterization of a human hyperimmune intravenous immunoglobulin against Pseudomonas aeruginosa and Klebsiella species. I Infect Dis 163, 1055-1061.

Gibb, A. P., Barclay, G. R., Poxton, I. R. \& Di Padova, F. (1992).
Frequencies of lipopolysaccharide core types among clinical isolates of Escherichia coli defined with monoclonal antibodies. $J$ Infect Dis 166, 1051-1057.

Holst, O. \& Brade, H. (1992). Chemical structure of the core region of lipopolysaccharide. In Bacterial Lipopolysaccharides, Vol. I, Molecular Biochemistry and Cellular Biology, pp. 135-170. Edited by D. C. Morrison \& J. L. Ryan. Boca Raton: CRC Press.

Kirkland, T. N. \& Ziegler, E. J. (1984). An immunoprotective monoclonal antibody to lipopolysaccharide. J Immunol 132, 25902592.

Lugowski, C., Czarny, A., Jachymek, W. \& Romanowska, E. (1992). Protective activity of antisera against core type R 1 and R4 oligosaccharides conjugated with tetanus toxoid. In Program Abstracts: 2nd Conference of the International Endotoxin Society, abstract 279.

Nnalue, N. A., Lind, S. M. \& Lindberg, A. A. (1992). 'The disaccharide $\mathrm{L}-\boldsymbol{\alpha}$-D-heptose $1 \rightarrow 7$-L- $\alpha$-D-heptose $1 \rightarrow$ of the inner core domain of Salmonella lipopolysaccharide is accessible to antibody and is the epitope of a broadly reactive monoclonal antibody. $J$ Immunol 149, 2722-2728.

Ørskov, K. \& Ørskov, I. (1984). Serotyping of Eschericbia coli. Methods Microbiol 14, 42-112.

Viret, J.-F., Bruderer, U. \& Lang, A. B. (1992). Characterization of the Shigella serotype $\mathrm{D}$ (S. sonnei) $\mathrm{O}$ polysaccharide and the enterobacterial R1 lipopolysaccharide core by use of mouse monoclonal antibodies. Infect Immun 60, 2741-2747.

Received 21 July 1993; revised 6 October 1993; accepted 22 November 1993. 